\title{
Performance and Evaluation of the Heating Value of Wood Biomass for Use in Steam Thermal Power Plant
}

\author{
${ }^{1}$ P. Egbaelu, ${ }^{2}$ E. I Bello, ${ }^{3} \mathrm{O}$. Z Ayodeji \\ ${ }^{1}$ Department of Mechanical Engineering, Federal University of Technology, P.M.B 704, Akure, Ondo State, Nigeria \\ Email: kome4life22@gmail.com \\ ${ }^{2}$ Professor, Department of Mechanical Engineering, Federal University of Technology, P.M.B 704, Akure, Ondo State, Nigeria \\ Email:emmanuebello111@yahoo.co.uk \\ ${ }^{3}$ Ph.D., Department of Mechanical Engineering, Federal University of Technology, P.M.B 704, Akure, Ondo State, Nigeria \\ Email:gokeayodeji@gmail.com
}

\begin{abstract}
Wood biomass is a potential alternatives source of energy for electricity generation if well Harnessed. This is due to its prospect in the production of fuel having high calorific value that can be used to drive a steam turbine in the production of electricity. This study shows the Performance and evaluation of the heating values of wood biomass for use in steam thermal power plant. Biomass (wood wastes) from six tropical species, Iroko (Melicia Exclsa),Omo(Cordial Platythyrsa), Obeche (Tripochiton Scleroxylon), Afara (Terminal Superb), Ayin (Anogeissuseleio Carpus), Abura (Mirangya Cilita) collected from twelve(12) sawmills in Akure metropolis Ondo state in south west Nigeria, were used as a feedstock. The proximate and ultimate analyses were performed to access the energy characteristics of the collected wood samples according to the procedure of American Society Standard Test Material (ASTM) for ultimate and proximate analysis ASTM E870-82. A computer program (MATLAB) was developed to determine the calorific value, volume of air, consumption of water and steam require in powering a 1.0 MW-h steam thermal power plant (Model). The results from laboratory experiments and energy calculations from the model revealed that the six wood species used in this study contain relatively low moisture content and ash content, high proportion of volatile matter and high calorific value, low level of sulphur as well as a sufficient high value of thermal energy potential. The boiler efficiency, mass of air, volume of air, steam consumption of the six samples of wood at different air fuel ratio were determined. Furthermore the model required $7.985 \mathrm{~kg} / \mathrm{h}$ of wood waste, $13.206 \mathrm{~kg} / \mathrm{h}$ mass of water, 1.86 factor of evaporation and $7.1 \mathrm{~kg} / \mathrm{h}$ of steam consumption. The volume and mass of air require is $58.297 \mathrm{~m} 3 / \mathrm{h}$ and $318.813 \mathrm{~kg} / \mathrm{h}$ respectively.
\end{abstract}

Keywords: Wood Biomass, Steam, Calorific value, Thermal Power, Energy Potential.

\section{INTRODUCTION}

Energy demand, supply, and pricing have enormous impact on the socio-economic development, the living standards and overall quality of life of the population of a nation, Mohamad and Anuge, (2016). The form of energy that is very crucial for human existence is electrical energy as it tends to form the heart of any meaningful growth in any country. Throughout the world electricity is the most widely used and desirable form of energy Oyedepo (2012). It is the bedrock, indispensable driving force and essential ingredient as well as a basic requirement for socio-economic growth and development Oyedepo et al.(2015). Be it entertainment, recreation, agriculture, commerce, industry, transport, education, communication, health, architecture and many others Unachukwu et al., (2015).

However, the present dependence of the Nigerian government on hydro and fossil fuel resources (petroleum, coal and gas) to generate electricity is not enough to meet the energy demand of the population (which is approximately two hundred million people). This is based on the fact that the available megawatt-hour is not enough to cater for the teeming populace CEC (2002). However, Nigeria is endowed with abundance of renewable and non-renewable energy resources including Hydro, wind, solar energy etc. A proper leverage on this abundance of energy resources will enable proper development which is antigen to the development of any nation. On the other hand even though Nigeria is endowed with massive reserves of hydro energy, petroleum and gas, most of the country's citizens do not have access to uninterrupted supplies of electricity Ubani, (2013). Electricity outage is one of the main challenges confronting the residential, commercial and industrial sectors of Nigeria's economy. And all attempts at addressing this problem have not yielded the desired results Nwachukwu et al., (2014). Energy sufficiency and security is a key to development and prosperity since it provides essential inputs for socio-economic development at regional, national and sub-national levels; thereby providing vital services that improve the quality of life Singh and Sooch, (2004). The 
access to affordable energy is an essential component of achieving the Millennium Development Goals and UN Sustainable Development Goals for Nigeria, Amigun et al., (2011).

Today, every country draws its energy needs from a variety of sources. Energy sources therefore, have to be explored and developed to enhance industrial breakthrough, national security and financial stability of the nation. Biomass is one of these sources. Biomass is a non-fossilized and biodegradable organic material that originated from plant, animals and micro-organisms which could be residues/waste from forestry and agricultural product, including the waste from the municipalities. It is available in varying forms throughout the developing World. Ohimain (2011). Osafehinti and Ayodeji (2018) observed that among various source of biomass which comprises palm kernel shells, municipal wastes, wood and its waste is a very cheap source of fuel when properly harnessed.

In Nigeria, about 11 million hectares of forest and 5.5 million hectares of other wooded land are available; according to the Food and Agriculture Organization (FAO) (2016), Logging activities in the forests and wood processing at the various wood processing industries generate a huge volume of wood wastes annually across cities in the country. For example, about 294,798 tonnes of wood waste is generated yearly in the city of Lagos Kehinde et al (2014). Aina, (2016), estimated that about $2288 \mathrm{~m} 3$ of wood wastes are generated daily in Abeokuta, while Dosunmu and Ajayi (2002) reported that 5.2 million tonnes of wood wastes are generated from the Nigerian sawmills per year. These quantities of wood could be harnessed to generate electricity, heat and transport fuels by using several technologies available such as direct combustion, gasification and pyrolysis Armau (2013). In 2015, about $46 \%$ of renewable energy consumed in European Union (EU) came from solid biomass Bourguignon, (2015), in 2013, solid biomass accounted for 3\% of the electricity produced in the EU and $15 \%$ of the heat produced in the industrial sectors. The use of woody biomass for energy generation can offset fuels such as coal, gasoline, natural gas and oil Basker et al (2012). Such practice can enhance economic development, foster new industries and encourage green economy as well as energy independence.

This work focuses on the Evaluation of the heating values of wood biomass for use in steam thermal power plant. The study intends to access the energy content of the selected wood, moisture content and their various calorific values for effective and efficient electrical energy generation.

Therefore, this study assessed the performance and evaluation of the heating value of wood biomass for use in steam thermal power plant, which include proximate and ultimate analysis of six species of wood, develop a model for determining the calorific values of wood and estimating the mass of air and water consumption at different air fuel ratio.

\section{MATERIALS AND METHODS}

The materials and method used for the study are as follows:

\subsection{Materials}

Wood biomass from six tropical species were collected from sawmills and wood markets across Akure metropolis in Ondo States in south western part of Nigeria. The wood species (wood samples), were: Obeche (Tripolochiton sclerxylon) ,Iroko (Milicia excelsa), Afara (Terminallia superba), Ayin (Anogeissusleiocarpus), Abura (Mitragyna Ciliata),Omo (Cordia Millenii).

\subsection{Methods}

Wood processing activities were physically observed for 5 day/week at the various sawmills and wood markets visited for eight (8) consecutive weeks to collect each of the samples of wood (sawdust and pellet). The sample collected were sun dried to reduce moisture content and to prevent degradation. Experiments were carried out on each sample to determine their moisture content as well as their proximate and ultimate analyses. The experiments were conducted according to the procedure of the America Society Standard Test Method (ASTM) for ultimate and proximate analysis (ASTM E870-82(2013). A model was developed with Matlab computer language for estimating the heating values of selected wood sample (including any kinds) and computing quantities of fuel samples (wood biomass), water and steam required to generate $1.0 \mathrm{MW}$-h of electrical energy.

\subsubsection{Estimation of the volume wood (waste/ pellet)}

The volume of weekly milled wood (VWW) base on six working days was given by equation 1 . 
$v w w=6 * 0.8164 N L D$

$V W W=4.898 N L D$

Where:

NLD = Number of lumber per day

\subsubsection{Proximate and Ultimate Analyses}

The proximate analysis determine the physiochemical properties of the biomass like moisture content, fixed carbon, volatile matter and ash content, while ultimate analysis determine the elemental composition of carbon, hydrogen, oxygen and sulphur.

The following equation were used to determine the parameters

\subsubsection{Moisture Content}

Moisture content (MC) is given below

$$
M C=\frac{\text { Initial weight }- \text { Final weight }}{\text { Initial weight }}
$$

2.2.2.2 Ash content (AC)

$$
\begin{aligned}
& A C=\frac{\mathrm{M}}{\mathrm{Ms}} \times 100 \% \\
& M=\text { Mass of the Ash } \\
& M s=\text { mass of the sun dried sample }
\end{aligned}
$$

\subsubsection{Volatile Matter Content}

The volatile matter (VM) is given below

$V M=\frac{\mathrm{W}-\mathrm{Z}}{\mathrm{W}} \mathrm{X} 100$

$W=W$ eight of sun dried pellets

$\mathrm{Z}=$ Weight of dried wood pellet

\subsubsection{Fixed Carbon Content}

Fixed carbon (FC) is given below

$F C \%=100-M C-V M-A C \%$

2.2.2.5 Mathematical model to determine the calorific value of various woods

$C_{v, S}($ in $\mathrm{kJ} / \mathrm{kg})=33440 . C+115300 \cdot H+9279 . S-2440 . H_{2} \mathrm{O}$

Where: $\mathrm{C}$ is the carbon content (\%);

$\mathrm{H}$ is the hydrogen content (\%); $\mathrm{S}$ is the sulphur content (\%); and $\mathrm{H}_{2} \mathrm{O}$ is the water content (\%) 
2.3 Determination of the turbine internal efficiency

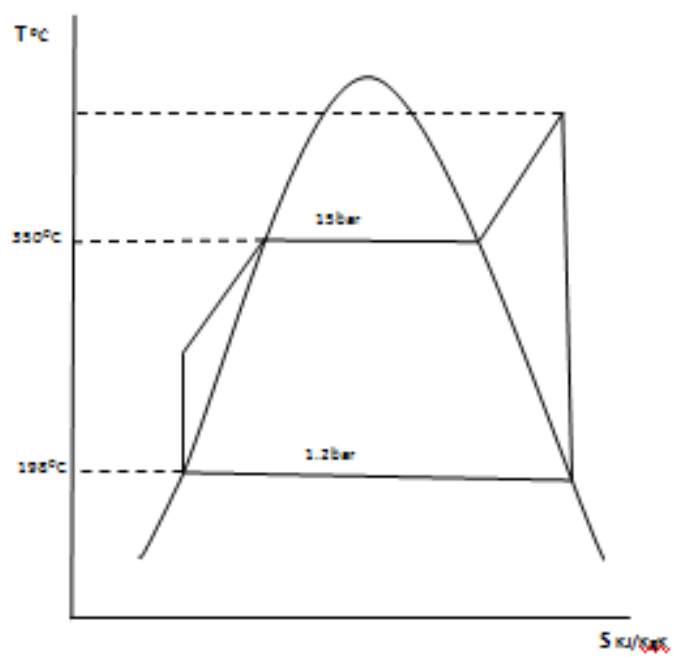

Figure 1: shows the T-S diagram of 1.0 MW-h waste wood steam thermal power plant (WWSTPS)

Table 3.1 showing Conditions of steam at inlet temperature $\left(350^{\circ} \mathrm{C}\right)$

The internal efficiency of the turbine was evaluated using equation 7 and 8 as given by Chattopadyay, (2004)

$\eta_{\mathrm{t}}=\frac{\mathrm{h}-\mathrm{h}_{2}}{\mathrm{~h}-\mathrm{hf} \mathrm{f}_{2}}$

\begin{tabular}{|l|l|l|l|l|l|l|}
\hline Pressure $(\mathbf{b a r})$ & $\mathbf{V}\left(\mathbf{m}^{\mathbf{3}} / \mathbf{k g}\right)$ & $\mathbf{h}_{\mathbf{f}}(\mathbf{k J} / \mathbf{k g})$ & $\mathbf{h}_{\mathbf{f g} 2}(\mathbf{k J} / \mathbf{k g})$ & $\mathbf{S}_{\mathrm{f} 2}(\mathbf{k J} / \mathbf{k g k})$ & $\mathbf{S}_{\mathrm{fg}}(\mathbf{k J} / \mathbf{k g k})$ & $\mathbf{T}_{\text {sat }}\left({ }^{\mathbf{0}} \mathbf{C}\right)$ \\
\hline 15 bar & 278.5 & 844.7 & 1945.2 & 6.978 & 4.1261 & 198.3 \\
\hline 1.2 bar & & 439.7 & 2244.1 & 1.3609 & 5.937 & \\
\hline 15 bar and $350^{\circ} \mathrm{C}$ & & $\mathrm{h}^{*}=3147.5$ & & $\mathrm{~s}^{*}=7.102$ & & \\
\hline
\end{tabular}

The adiabatic enthalpy drop

$(\Delta \mathrm{h})=h-h_{2}$

\subsection{Determination of the work done}

Impulse steam turbine was considered because it is a single state process. Turbine and pump are the two work utilizing components involved in the energy generation. The turbine work done (Wexp) according to Nag (2008) is the product of the adiabatic enthalpy drop and the stage internal efficiency. It is express in equation 9:

$W \exp =\Delta \mathrm{h} \cdot \eta_{\mathrm{t}}$

2.5 Mass of Fuel Charged to the Boiler

Actual mass of fuel charged to the boiler is

Addition of mass of fuel to unburnt mass of fuel

$\mathrm{Mfa}=m f+\mathrm{mfu}$

$M f a=(1+\sigma f) m f$

Where Mfa is actual mass of fuel, $m f$ mass of fuel, mfu mass of unburnt fuel, $\sigma f$ is fraction of unburnt fuel, 


\subsection{Determination of Factor of evaporation $\left(F_{\mathrm{ev}}\right)$}

The factor of evaporation is given by equation (11)

$F_{e v}=\frac{\mathrm{Hf}+\mathrm{Lv}+\mathrm{Cp} \Delta \mathrm{t}-\mathrm{Hfw}}{\mathrm{Hw}}$

Where: Hf is enthalpy of steam, Lv is latent heat of vapourization,

Cp is specific heat capacity of steam, $\Delta \mathrm{t}$ is temperature difference, Hfw is enthalpy of feed water, at ambient temperature Hw is enthapy of waterat boiling temperature

\subsection{Mass of Water Required}

$M R q=F e v \cdot M s t$

Where: Fev Is factor of evaporation, Mst is mass of steam

Boiler efficiency which is the ratio of the heat load of the generated steam to the heat supplied by the fuel(wood) over the same period as express in the equation 13 by $\mathrm{Nag}(2008)$ as:

Boiler efficiency $=\frac{\text { heat output }}{\text { heat input }}$

$\eta_{\boldsymbol{b}}=\frac{\text { Mst. } \Delta \mathrm{h}}{m f(1+\varphi) C v}$

Where

$\eta_{\boldsymbol{b}}$ is boiler efficiency, Mst is mass of steam $\Delta \mathrm{h}$ is adiabatic drop in the boiler, $\varphi$ is air fuel ratio, Cv is calorific value,

\subsection{Air required in the system}

Air fuel ratio $=\frac{\text { mass of air }}{\text { mass of fuel }}$

$M a=m f \cdot \varphi$

$M a c=(1+\varphi) m f$

Where, Mac is actual mass of air , $m f$ mass of fuel, $\varphi$ is air fuel ratio, Ma is mass of air

\subsection{Volume of air (va)}

volume of air $=\frac{\text { mass of air }}{\text { density of air }}$

$v a=\frac{\mathrm{ma}}{\rho_{a}}$

$v a=\frac{(1+\varphi) m f}{\rho_{a}}$

\subsection{Determination of thermal power potential of the plant}

power $=\frac{\rho_{w d} * V d * \mathrm{CV} *^{\mathrm{n}} \mathrm{int}}{3600}$ 
Where: $V d W$ is the volume of daily milled wood waste $\left(\mathrm{m}^{3}\right), \rho_{w d}$ is the density of the wood species $\left(\mathrm{kg} / \mathrm{m}^{3}\right.$ and $\mathrm{CV}$ is the calorific value $(\mathrm{Mj} / \mathrm{Kg}), \eta$ int is turbine efficiency.

\section{RESULTS AND DISCUSSION}

\section{Proximate Analysis}

The result of the proximate analysis of the various sample are presented in table 3.1

\section{Proximate Analysis of Selected Wood Biomass Material}

Table 3.1 proximate analysis of the selected wood biomass

\begin{tabular}{|l|l|l|l|l|}
\hline Types of wood & Moisture Content (\%) & Ash Content (\%) & Volatile Matter (\%) & Fixed carbon (\%) \\
\hline Abura & 7.1 & 1.68 & 77.48 & 13.77 \\
\hline Iroko & 8.9 & 4.64 & 82.44 & 3.96 \\
\hline Afara & 3.52 & 1.95 & 82.17 & 12.36 \\
\hline Omo & 6.4 & 1.07 & 85.57 & 6.96 \\
\hline Ayin & 15.2 & 0.71 & 80.62 & 4.0 \\
\hline Obeche & 2.3 & 2.71 & 82.73 & 11.94 \\
\hline
\end{tabular}

Table 3.1 shows that the percentage moisture content range from $2.3 \%$ to $15.2 \%$ and Ayin had the highest with $15.2 \%$ while that of the Obeche had the least $2.3 \%$ follow by Afara with $3.52 \%$. The results agreed with the finding of Ogunsola et al (2018) that the moisture content ranges from 2.0 to $16.02 \%$. This shows that Obeche is the one with the highest durability value in terms of their storage. The relatively low moisture content favours thermo-chemical conversion, since high moisture content reduces the efficiency of the system and also reduces the energy available from wood wastes during combustion as heat would be required to vaporize the water Yang et al (2005) The percentage volatile matter of the samples ranges from 77.48 to $85.57 \%$, this results agreed with the findings of Akihito et al (2017), Ogunsola et al (2018). Who reported that the volatile matter of wood ranges from 71.01 to $87.70 \%$, with Omo having the highest value and Abura with the least value. The volatile matter strongly influences combustion behaviour of solid fuel. Loo (2008).

The Ash content of the sample ranges from 0.71\% ( Ayin) to 4.64\% ( Iroko). The result agreed with the findings of Akinola and Fapetu (2015) ranges from 0.78 to $4.89 \%$. The high Ash content for Iroko indicates that it has a high mineral matter. All other Ash content obtained in this study was lower than $4 \%$. This indicates that slagging (an incombustible by products) might not occur in other species of wood samples except for that of Iroko are used as biomass fuel. This low ash content is a desirable factor for energy generation and this aligns with the finding of Loo and koppejan (2008) that the higher the ash content in a fuel the lower its heating value.

The fixed carbon content of the wood sample varied from $3.96 \%$ Iroko to $13.77 \%$ of Abura. The result agreed with the findings of Ogunsola et al (2018) that the fixed carbon content ranges from 3.89 to $17.75 \%$. The high fixed carbon contents indicate that biomass will require a long combustible time. The results shown from table 3.1 indicates that these wood samples will have ease of burning and stable flame during combustion as well as high heating value.

Table 3.2 Ultimate analysis of the wood selected samples

\begin{tabular}{|l|l|l|l|l|}
\hline Wood type & $\begin{array}{l}\text { Hydrogen } \\
\text { content }(\% \text { vol })\end{array}$ & $\begin{array}{l}\text { Carbon content } \\
(\% \text { vol })\end{array}$ & $\begin{array}{l}\text { Oxygen content } \\
(\% \text { vol })\end{array}$ & $\begin{array}{l}\text { Sulphur content } \\
(\% \text { vol })\end{array}$ \\
\hline Abura & 5.03 & 45.27 & 41.00 & 0.02 \\
\hline Iroko & 5.34 & 26.56 & 46.72 & 0.03 \\
\hline Afara & 5.56 & 57.00 & 35.86 & 0.05 \\
\hline Omo & 3.10 & 48.21 & 42.22 & 0.02 \\
\hline Ayin & 4.03 & 38.14 & 44.50 & 0.04 \\
\hline
\end{tabular}




\begin{tabular}{|l|l|l|l|l|}
\hline Obeche & 4.32 & 32.24 & 36.15 & 0.03 \\
\hline
\end{tabular}

The results obtained from the six pellets sample are shown in table 3.2 indicate that the value of Hydrogen range from 3.10\% o( Om)o to 5.56\% (Afara). This shows that the species has a good heating values having fall below 6\%. The carbon content ranges from $26.56 \%$ Iroko to $57 \%$ for Afara. The oxygen content varied from $35.86 \%$ for Afara to $46.72 \%$ (Iroko), and finally the sulphur content ranges between 0.02 (Omo) to 0.05 (Afara). The results agreed with the findings of Ogunsola et al (2018). The high carbon content is expected to increase the calorific value of the fuel. The figure also reveals high percentage of hydrogen and oxygen; depict high energy potential of the wood samples. the results, agreed with the finding of Akhator et al (2017) who reported an oxygen content and hydrogen content of 5.1 to $5.59 \%$ and 35.8 to $39.11 \%$ and sulphur content from 0.03 to $0.06 \%$. Carbon, hydrogen and oxygen are the major components of biomass feedstock and the reactants required during combustion process. It can be seen from the figure that the wood species contain low level of sulphur as required by the DIN51731 and as affirmed by Akhator et al (2017).

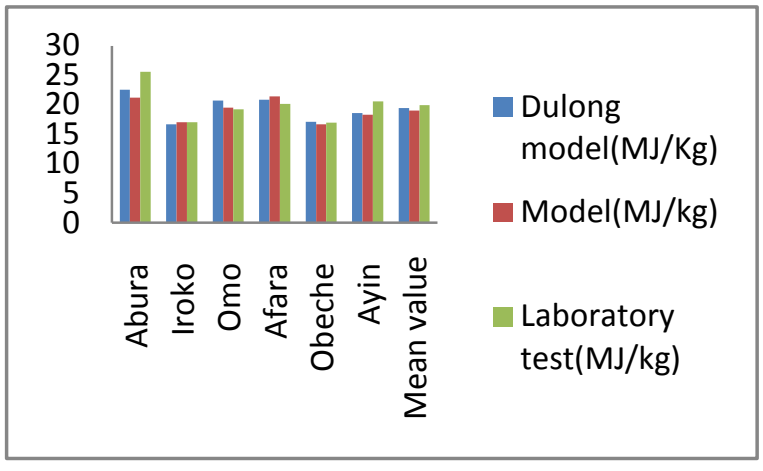

Figure 3.1 Comparison of the GCV experimental with the design model and Dulong Berthelot model

The mean calorific value of $19.04 \mathrm{MJ} / \mathrm{kg}$ and $19.98 \mathrm{MJ} / \mathrm{kg}$ from both the laboratory analysis, and the model, both agreed with the findings of Nag (2011) and Rajput (1997) and that of Dulong model which ranges from $15.8 \mathrm{MJ} / \mathrm{kg}$ to $26 \mathrm{MJ} / \mathrm{kg}$. The result indicate good energy contents and also agreed with that of Akhator et al(2017) and Ogunsola et al(2018). Who reported that the calorific values of wood ranges between $17.5 \mathrm{MJ} / \mathrm{kg}$ to $26.2 \mathrm{MJ} / \mathrm{kg}$ and those calorific values of wood does not vary much from one species to another.

Table 3.3: The summary of the average volume of wood wastes and log generated on a daily basis for the 12 sawmills visited in Akure for this study

\begin{tabular}{|c|c|c|c|c|c|c|c|}
\hline $\mathbf{S} / \mathbf{N}$ & Name of Sawmill & $\begin{array}{l}\text { Average number } \\
\text { of } \log \text { per } \operatorname{day}\left(\mathrm{Ft}^{3}\right)\end{array}$ & $\begin{array}{l}\text { Average } \\
\text { of } \quad \log \quad \text { per } \\
\text { week }\left(\mathrm{Ft}^{3}\right)\end{array}$ & $\begin{array}{lr}\begin{array}{l}\text { Average } \\
\text { of }\end{array} & \begin{array}{r}\text { number } \\
\text { lumber }\end{array} \\
\text { produced } & \text { per } \\
\text { day }\left(\mathbf{F t}^{3}\right) & \\
\end{array}$ & $\begin{array}{l}\text { Average number } \\
\text { of lumber per } \\
\text { week }\left(\mathrm{Ft}^{3}\right)\end{array}$ & $\begin{array}{l}\text { Average volume of } \\
\text { waste generated } \\
\text { per } \operatorname{day}\left(\mathrm{m}^{3}\right)\end{array}$ & $\begin{array}{lr}\text { Average } & \text { waste } \\
\text { generated } & \text { per } \\
\text { week }\left(\mathbf{m}^{3}\right) & \end{array}$ \\
\hline 1 & Babatunde F.A & 5 & 15 & 288 & 2016 & 55.71 & 334.26 \\
\hline 2 & Alahaji Disu & 3 & 8 & 432 & 3456 & 36.5 & 219.0 \\
\hline 3 & Aswara plc & 4 & 8 & 144 & 720 & 51.1 & 306.6 \\
\hline 4 & Osbondu & 5 & 10 & 288 & 2880 & 81.2 & 487.2 \\
\hline 5 & Bosan & 4 & 11 & 504 & 6048 & 58.9 & 353.4 \\
\hline 6 & Adekoya & 3 & 13 & 576 & 8084 & 62.9 & 377.4 \\
\hline 7 & Bolaji & 3 & 9 & 436 & 5232 & 92.8 & 556.8 \\
\hline 8 & Tony S & 5 & 15 & 720 & 4320 & 64.8 & 388.8 \\
\hline 9 & Owadasha & 4 & 9 & 360 & 3240 & 75.8 & 454.8 \\
\hline 10 & Mukola & 4 & 10 & 648 & 1788 & 68.2 & 409.2 \\
\hline 11 & Ifeoluwa & 3 & 9 & 298 & 2317 & 67.3 & 403.8 \\
\hline \multirow[t]{3}{*}{12} & Ajibade & 3 & 12 & 331 & 3120 & 65.3 & 391.8 \\
\hline & Total & 42 & 129 & 5025 & 43221 & 790.51 & 4743.06 \\
\hline & Mean & 3.5 & 10.75 & 418.75 & 3601.75 & 65.88 & 395.255 \\
\hline
\end{tabular}


The table shows the total of $461.3 \mathrm{~m}^{2}$ of daily $\log$, and a total of $2767.8 \mathrm{~m}^{2}$ per week. a total volume of $790.51 \mathrm{~m}^{3}$ per day and $4743.06 \mathrm{~m}^{3}$ weekly.

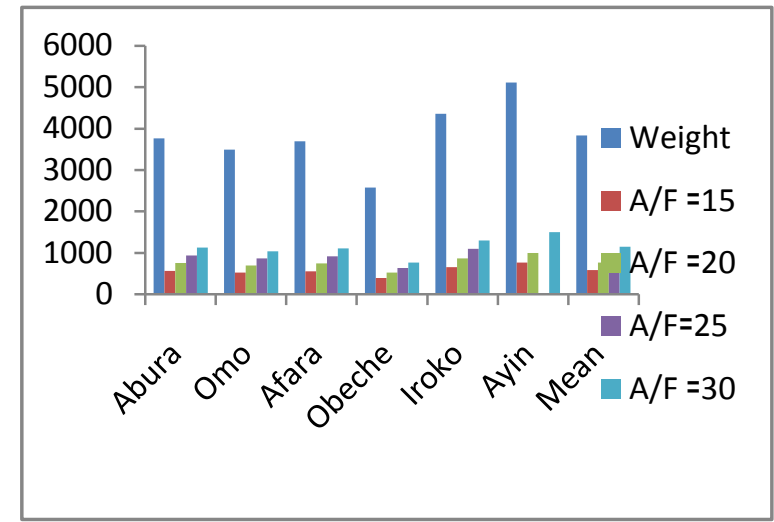

Figure 3.2: Mass of Air at different Air fuel Ratio

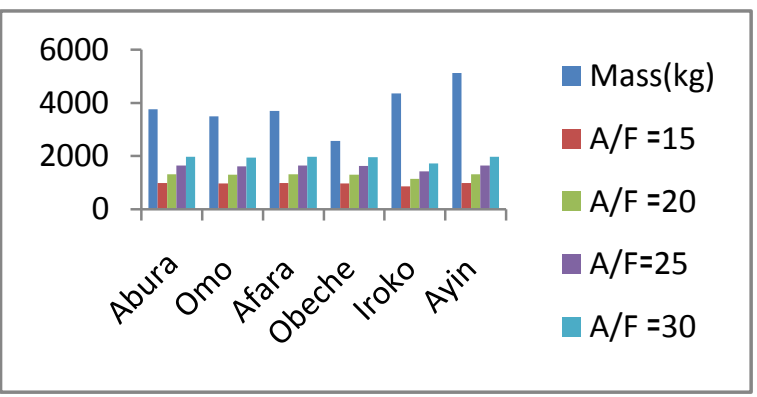

Figure 3.3 Volume of air at different air fuel ratio

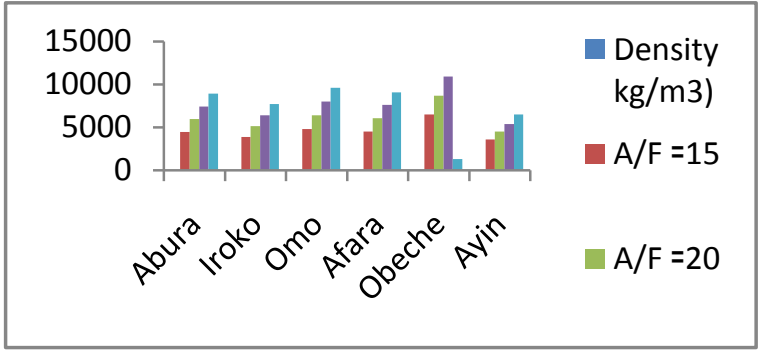

Figure 3.4 steam consumption using each wood species at different air fuel ratio

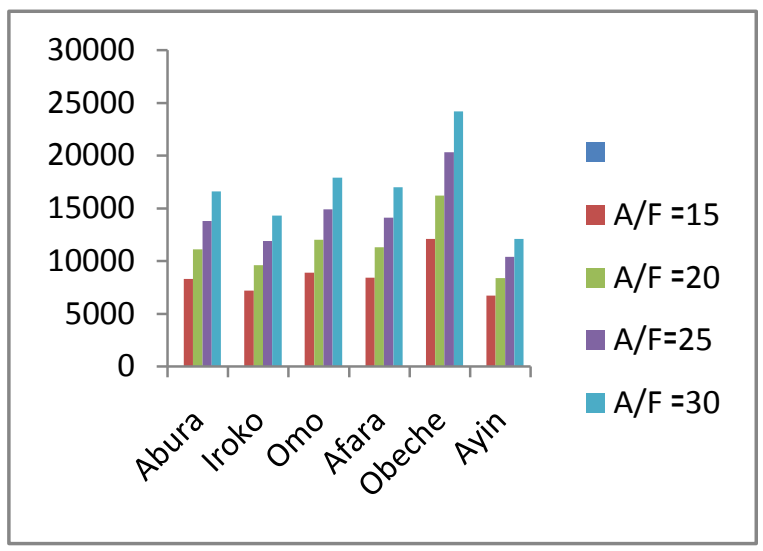

Figure 3.5 rate of water require by each specie at different air fuel ratio 


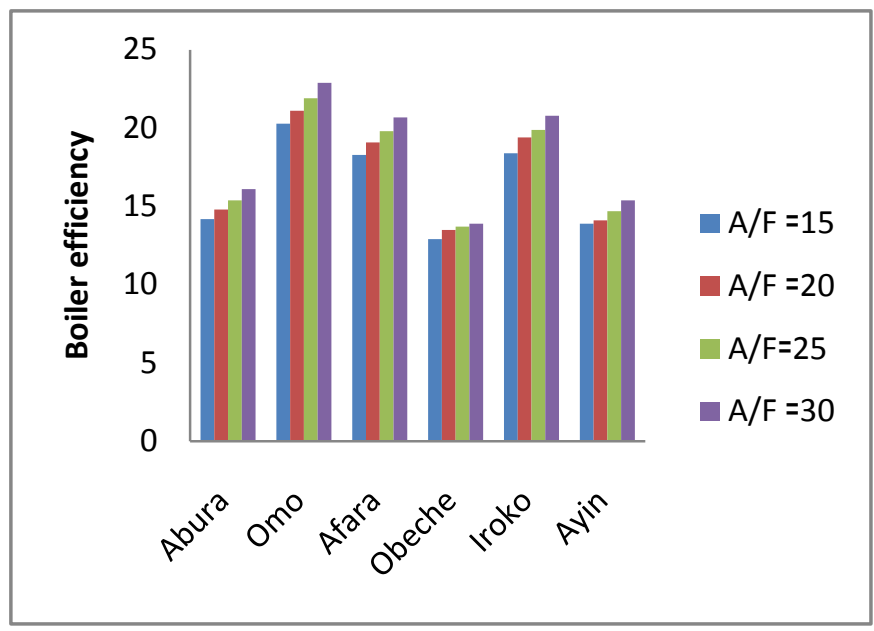

Figure 3.6 Boiler efficiency at different air fuel ratio

\section{Thermal power potential(MW-h)}

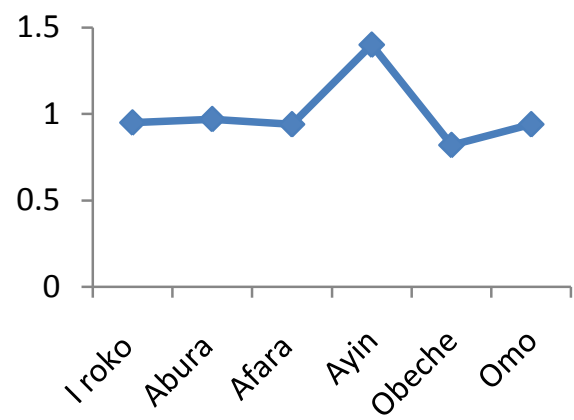

- Thermal power potential(MW-

h)

Figure 3.7 Thermal power potential of wood sample

Figure 3.2 to 3.7 shows the mass of air, volume of air, boiler efficiency, water requirement, steam consumption and thermal potential of the six sample of wood at different air fuel ratio. The results shows that as the air fuel ratio increases the mass of air, volume of air, steam consumption, water requirement and the performance of the boiler also increases. The result also shows that Obeche performance is the least $12.2 \%$ at $15: 1$ to $13.9 \%$ at $30: 1$ and the highest is omo with 20.3 to 22.9 at $15: 1$ and $30: 1$ respectively. Also the mass of fuel affect the boiler efficiency, the higher the quantity of wood charged into the furnace the higher the performance of the boiler. This result agrees with the findings of Damilola et al (2021) which ranges between 16 to 26.5 . Furthermore the cost of design is higher with high Air fuel ratio according to Damiloloa et al (2021). Figure 3.8 shows that, Ayin has the highest thermal power potential and Obeche has the least. From their mean performance the selected wood sample has a good power generating potential, however due to their economic value, cost and availability, afara wood is more suitable for power generation due to its availability, having shown to have good calorific value and good thermal potential.

\subsection{Summary of results of the different stages of the thermal plant model}

\begin{tabular}{|l|l|l|l|}
\hline S/N & PARAMETERS & EQUATION & $\begin{array}{l}\text { CALCULATED } \\
\text { VALUES }\end{array}$ \\
\hline 1 & Adiabatic enthalpy drop of turbine & $\Delta \mathrm{h}=h-h_{2}$ & $585.2 \mathrm{KJ} / \mathrm{KG}$ \\
& & & \\
\hline
\end{tabular}




\begin{tabular}{|c|c|c|c|}
\hline 2 & Work done by turbine & $W \exp =\Delta \mathrm{h} \cdot \eta \operatorname{int}$ & $379 \mathrm{KJ}$ \\
\hline 3 & Dryness factor & $h_{2}=h_{f 2}+x \cdot h_{f g 2}$ & 0.946 \\
\hline 4 & Rate of Steam consumption & $M s t=\frac{2685.6}{\text { Wexp }}$ & $7.1 \mathrm{Kg} / \mathrm{h}$ \\
\hline 5 & Factor of evaporation & $F e v=\frac{\mathrm{Hf}+\mathrm{Lv}+\mathrm{Cp} \Delta \mathrm{t}-\mathrm{Hfw}}{\mathrm{Hw}}$ & 1.86 \\
\hline 6 & Mass of water required & $M R q=F e v \times M s t$ & $13.206 \mathrm{Kg} / \mathrm{h}$ \\
\hline 7 & Mass of fuel charged & $M f a=(1+\sigma f) m f$ & $5.304 \mathrm{~T} / \mathrm{h}$ \\
\hline 8 & Mass of air require & $M a c=(1+\varphi) m f$ & $318.813 \mathrm{~kg} / \mathrm{h}$ \\
\hline 9 & Volume of air require & $v a=\frac{(1+\varphi) m f}{\rho_{a}}$ & $58.297 \mathrm{~m}^{3} / \mathrm{h}$ \\
\hline 10 & Power potential of wood sample & power $=\frac{\rho_{w d} * V d * \mathrm{CV} *{ }^{n} \text { int }}{3600}$ & 1.00 MW-h \\
\hline
\end{tabular}

\section{CONCLUSION}

This study assesses the performance and evaluation of the heating value of wood biomass for use in steam power plant. The volume of wood waste per wood specie has been identified and the heating value of the fuels identified. A model for determining the calorific value of wood has been developed using their proximate and ultimate analyses result. The study revealed that, the wood species had a calorific value ranging from 16.96 to $25.5 \mathrm{MJ} / \mathrm{kg}$ and a thermal potential ranging from 0.82 to $1.4 \mathrm{MW}$-h.

It then be concluded that large and significant energy contents are stocked in wood and can be converted to use as alternative source of energy either for heating or for electricity generation.

\section{REFERENCES}

[1] Aliyu, A.S, Dada, J.O. and Adam, I.K. (2015). 'Current status and future prospects of Renewable energy in Nigeria', Renewable and Sustainable Energy Reviews, 48:336-346.

[2] Akhator E .P, Obanor A .I, Ugege A. O, (2017). Physio/chemical properties and energy potential of wood wastes from sawmills in Benin metropolis, Nigeria. Nigeria Journal of Technology, 36:452-456.

[3] Akinola A .O and Fapetu O. P,(2015) characteristics study of wood wastes from sawmills, Akure Nigeria. British Journal of Applied Science and Technology 6:610-612.

[4] Amigun, B, Musango, J.K. and Stafford, W. (2011). 'Biofuels and sustainability in Africa', Renewable and Sustainable Energy Reviews, 15: 1360-1372.

[5] ASTM E870-82(2013). Standard Test Methods for Analysis of Wood Fuels, ASTM International, West Conshohocken, PA, 2013, www.astm.org

[6] Alice. F, Julia .S, Vanise, C.M. And Andreas. S, (2017). The use of Biomass for Electricity Generation: A Scoping Review of Health effects on Human in Residential and Occupational Settings. International Journal of Environmental Research and Public Health. 15, 354, Doi: 10.3390/ijerph15020354.

[7] Arnau.G.J. (2013). Potential for Electrical Power Generation using Forest Wood Biomass in Rural Area of Catalonia. A Thesis Submitted to the School of Postgraduates Studies Purdue University, West Lafayette Indiana, United State of America. In partial Fulfilment of the requirements for the award of Master of Science degree in Electrical Engineering. Access June 6, from htts://docs.lib.purdue.edu/open-access-theses/53.

[8] Aina O.M (2013), wood waste utilization for energy generation. International Conference on Renewable Energy For developing Countries. 15(12): 206-213.

[9] Balogun, B. O. (2015). 'Potentials for sustainable commercial biofuels production in Nigeria', STECH, 4(2): 25-40. Chalmers University of Technology, and the Copernicus Institute of the University of Utrecht, UK. 
ISSN (online): 2581-3048

Volume 5, Issue 12, pp 73-83, December-2021

https://doi.org/10.47001/IRJIET/2021.512015

[10] Bourguignon, D. (2015): Biomass for electricity and heating: opportunities and challenges. http://www.europarl.europa.eu/Reg data/etudes/BRIE/2015/568329/ EPRS BRI (2015) 568329EN.pdf. Assessed September 25, 2016.

[11] Baskar,C., Baskar, S., Dhillion,R.S(2012): Biomass conversion, The Interface of Biotechnology, Chemistry and Materials Science, Springer, Berlin, Germany.

[12] Chattopanadhyay, P. (2004): "Boiler Operation Engineering Questions and Answers" Second Edition, India, Tata McGraw-Hill Ltd.

[13] Christus, J.S, Joseph, S.S. and Thyagarajan, K. (2014). Performance Studies on Downdraft Gasifier with Biomass Energy Sources Available in Villages. American Journal of Appiled Science, 11(4):611-622.

[14] DIN51731.( 2006)Testing of solids fuels compressed untreated wood, requirements and testing. Deutshes institute for Normung, Berlin.

[15] Energi .S. (2012). Technology data for energy plants-generation of electricity and district Heating, energy storage and energy carrier generation and coversion.energnit.dk, Denmark.

[16] FAO (2009). The State of Food and Agriculture, pp.150-180, FAO United Nation,Rome [online]http://www.fao.org/docrep/012/i0680e/i0680e.pdf (accessed 19 June 2018).

[17] Huhtinen, M.(2009),Wood energy as a fuel. Materials for 5EURES Training session, NCP, Finland. File://M/5Eures/WoodpropertiesPDF.htm, Accessed August15, 2016.

[18] IEA Bioenergy (2009). Bioenergy - A Sustainable and Reliable Energy Source: a Review of Status and Prospects, pp.1108, Energy Research Centre of the Netherlands (ECN), E4tech.

[19] Kehinde .O, Godswill .M, Anita.P, and Tobias .R. (2014). Nigeria wood waste: A Dependable and Renewable fuel option for power production. Journal of engineering and technology, 234-248.

[20] Mohamad, M. And Anuge, J. (2016). The Challenge for Future Sustainable Development. In Power Sector, pp.1-17, World Association of Sustainable Development $\quad$ (WASD) UK http://usir.salford.ac.uk/37674/7/Mostafa\%20Mohamad.pdf (accessed 9 June 2016).

[21] Muhammad, M.B. (2016). Effect of Gasification operating Parameters on Quality of Syngas Produced using sawdust feedstock. A dissertation submitted to the school of postgraduate studies Ahmadu Bello University, Zaria. In partial fulfilment of the requirement for the award of Master of Science Degree in Chemical Engineering. Accessed April 18, 2016 from kubanni.abu.edu.ng/jspui/bitstream/123456789/8068

[22] Nag P. K. (2011): Power Plant Engineering Third Edition: Tata McGraw-Hill New Delhi.

[23] Nwaokocha, C.N. and Giwa, S.O. (2016). 'Investigation of bio-waste as alternative fuel for Cooking', in 3rd International Conference on African Development Issues (CU-ICADI), Covenant University, Ota, Nigeria, 9-11 May 2016, pp.1-5 [online] http://cu-icadi.covenantuniversity.edu.ng (accessed 15 May 2017). Ed. Delhi: Rhanna Publishers.

[24] Ogunsola. O. A, Adeleke,O and Aruna, A.T (2018). Wood fuel analysis of some selected Wood species within Ibadan .International conference on science and sustainable development, vol 173:1315-1755.

[25] Ominiyi T. E, Amiandamhen, S.O, Amoo, K.(2019), Generations and potentials of sawmill wood wastes in Iwo, Osun States, Nigeria .Forestry Association of Nigeria (FAN).

\section{Citation of this Article:}

P. Egbaelu, E. I Bello, O. Z Ayodeji, "Performance and Evaluation of the Heating Value of Wood Biomass for Use in Steam Thermal Power Plant" Published in International Research Journal of Innovations in Engineering and Technology - IRJIET, Volume 5, Issue 12, pp 73-83, December 2021. Article DOI https://doi.org/10.47001/IRJIET/2021.512015 